МЕТОДОЛОГІЧНІ ЗАСАДИ ІННОВАЦІЙНОГО РОЗВИТКУ МАЙБУТНІХ ОФІЦЕРІВ ДЕРЖАВНОЇ КРИМІНАЛЬНО-ВИКОНАВЧОЇ СЛУЖБИ УКРАЇНИ КРІЗЬ ПРИЗМУ КРЕАТИВНОСТІ

\title{
METHODOLOGICAL FOUNDATIONS OF INNOVATIVE DEVELOPMENT OF FUTURE OFFICERS OF THE SCES OF UKRAINE THROUGH THE LENS OF CREATIVITY
}

Стаття присвячена пошуку напрямів вдосконалення інноваційного розвитку майбутніх офріцерів Державної кримінально-виконавчої служби України в закладі вищої освіти зі специфрічними умовами навчання.

Рефрормування багатьох сфер соиіального життя країни, зокрема й пенітенціарної, викликало нагальну потребу в підготовці офрічерів Державної кримінально-виконавчої служби нової формації. Зрозуміло, що якісна підготовка майбутніх фахівців, які спроможні вирішувати складні службово-профресійні завдання під час майбутньої діяльності, творчо та відповідально підходити до створення добропорядного й ефективного комунікативного середовища в пенітенціарних закладах, тобто гідного міжособистісного спілкування серед персоналу та спілкування з особами, які перебувають в умовах обмеження волі, а також загалом покращити роботу пенітенціарних закладів, неможлива без методологічного оновленні системи профресійної підготовки офріцерів-пенітенціаріїв в Україні.

Саме тому метою дослідження є визначення напрямів удосконалення методологічних засад інноваційного розвитку майбутніх офріцерів ДКВС України та їхніх сучасних професійних компетентностей крізь призму креативності процесу здобуття вищої освіти. Сорормувати майбутнього офріцера-пенітениіарія нової фооммаиіі як особистість у процесі здобуття ним вищої освіти на будьякому рівні сьогодні можна за допомогою різних соорм і методів навчання, що є складовими частинами методології навчання. Використання різних методологічних підходів щодо формування профресійних компетентностей майбутніх офріцерів-пенітенціаріїв тільки тоді стане ефрективним, коли кожний науково-педагогічний працівник буде креативно підходити до вибору та застосування інноваційних методів і форм проведення навчальних занять, застосову вати певні програмні продукти для розвитку майбутніх офріцерів як особистостей, профресіоналів, які здатні відповідально й вмотивовано підходити до самоконтролю результатів своєї службово-профресійної діяльності, мати стійке прагнення до підвищення рівня власного розвитку протягом усього життя.

Автором статті доведено, що в умовах стрімкої транссоормації суспільних відносин, особливо інформатизації й оновлення менеджменту системи вищої освіти, інноваційний розвиток майбутніх офріцерів Державної кримінально-виконавчої системи України може бути забезпечений формуванням у них креативного мислення та вміння творчо підходити до застосування набутих професійних компетентностей під час навчання в закладі вищої освіти зі специсрічними умовами навчання. Подальші дослідження будуть спрямовані на пошук нових креативних форм інноваційного розвитку і творчого мислення майбутніх офріцерів-пенітенціаріїв.
Ключові слова: просресійна підготовка осріцерів-пенітенціаріїв, методологія навчання, форми навчання, інноваційно-інформаційне освітнє середовище, креативне навчання, профресійні компетентності.

The article is devoted to searching directions of improving innovative development of future officers of the State Criminal and Executive Service of Ukraine in higher educational institution with specific studying conditions.

Reforming in many spheres of social life in the country, including the penitentiary one, has created an urgent need to train officers of the State Criminal and Executive Service of a new formation. It is clear that qualitative training of future specialists, who are able to solve complex jobprofessional tasks in future, create a decent and effective communication environment in penitentiary institutions creatively and responsibly, that is decent interpersonal communication between staff and communication with convicts, as well as to improve the work of penitentiary institutions in general, is not possible without methodological updating of the system of professional training of penitentiary officers in Ukraine. That is why the purpose of the research is to determine the directions of improving methodological foundations of innovative development of future officers of the SCES and their modern professional competences through the lens of creativity of higher education process.

Forming a future penitentiary officer of a new formation, as an individual in the process of obtaining a higher education at any level, is possible today with the help of various forms and methods of training that are integral to the methodology of training.

Using different methodological approaches in order to form future penitentiary officers' professional competencies will become effective only in that case, when each scientific and pedagogical worker will creatively select and applicate innovative methods and forms of training, use certain software products for the development of future officers as personalities, professionals who are able to approach the results of their professional activity responsibly and are motivated to strive for enhancing their own life-long development.

The author of the article has shown that in conditions of rapid transformation of social relations, especially informatization and updating of management of the higher education system, innovative development of future officers of the State Criminal and Executive System of Ukraine can be ensured by forming their creative thinking and ability to approach creatively the acquired professional competences while studying at a higher educational institution with specific studying conditions. Further research will focus on finding new creative forms of future penitentiary officers' innovative development and creative thinking. Key words: penitentiary officers' professional training, studying methodology, forms of studying, innovative and informative educational environment, creative training, professional competences. 
Постановка проблеми в загальному вигляді. Процес удосконалення та реформування національної системи освіти тісно пов'язаний із реформуванням і трансформацією всіх складових частин державної системи управління, зокрема Державної кримінально-виконавчої служби (далі - ДКВС) України. Це зумолює необхідність перегляду методологічних засад підготовки майбутніх фрахівців пенітенціарної сорери, формування їх як інноваційних особистостей, які мають бути обізнані в новітніх підходах та методах впливу на засуджених чи ув'язнених осіб, тобто мати сучасні погляди на застосування кримінально-виконавчого законодавства, як вітчизняного, так і закордонного, щодо впровадження міжнародних стандартів пенітенціарного менеджменту, дотримання прав людини тощо.

Система підготовки якісних офріцерів-пенітенціаріїв зіткнулася із цілою низкою проблем і соціальними змінами, які визначили нові вимоги до методології фрормування та якості профресійних компетентностей майбутніх офріцерів ДКВС України у сорері пенітенціарної педагогіки, пенітенціарної психології, соціальної роботи, пенітенціарного менеджменту, пробації, кримінології, дотримання вимог законодавства у кримінально-виконавчій сорері тощо.

Аналіз останніх досліджень і публікацій. Необхідно зазначити, що за останні п'ять років в Україні був зроблений певний прорив у напрямі популяризації знань у галузі пенітенціарної сфрери загалом, пенітенціарного менеджменту й імплементації міжнародного законодавства в галузі дотримання прав ув'язнених (засуджених), кваліфрікаційних вимог та профресійних компетентностей офріцерів-пенітенціаріїв тощо.

Різні аспекти в галузі професійної підготовки, освітньої методології формування професійних компетентностей офріцерів-пенітенціаріїв розглядали як вітчизняні, так і закордонні вчені, а саме: В. Болотов [1], І. Голубцова [2], К. Джонсон [3], Г. Драйден [4], І. Зимня [5], М. Кларін [6], Е. Койл [7], А. Либлинг [8], О. Пєхота [9], О. Пометун [10], П. Реста [11], В. Синьов [12], О. Тогочинський [13], О. Торічний [14], Е. Федорчук [15] та інші. В їхніх працях у загальному вигляді зазначені завдання щодо інноваційності підходів до фрормування професійних компетентностей і розвитку особистості майбутнього офріцера-пенітенціарія.

Більшість науковців зауважують застосування компетентнісного підходу в освітньому процесі, створення особливого освітнього середовища, упровадження інтерактивних методів, фрорм навчання, що сприяють інноваційному розвитку майбутнього офріцера-пенітенціарія, фрормуванню в нього механізмів адаптаційного, мотиваційного характеру та стійкого прагнення професійного вдосконалення протягом життя.
Виділення не вирішених раніше частин загальної проблеми. Варто констатувати, що для фрормування інноваційно розвинутої особистості майбутнього офріцера-пенітенціарія, його професійних компетентностей і досі існує потреба в більш глибокому вивченні напрямів удосконалення методологічних засад їх підготовки, оскільки на вимогу міжнародних стандартів офіцери кримінальновиконавчої сорери мають уміти застосовувати різні підходи до управління пенітенціарними закладами, уміти креативно вирішувати певні проблемі службово-профресійного характеру, є відповідальними за якість процесу ресоціалізації засуджених і деякою мірою за рівень безпеки суспільства.

Мета статті - визначення напрямів удосконалення методологічних засад інноваційного розвитку майбутніх офріцерів ДКВС України та їхеіх сучасних професійних компетентностей крізь призму креативності процесу здобуття вищої освіти.

Виклад основного матеріалу. Сьогодні в Україні загалом існують різні форми систем вищої ступеневої освіти, що базуються на певних принципах та підходах, головними з яких є: гарантійно-державний (спрямований на виконання освітніх стандартів і забезпечується фрінансуванням із бюджету країни); приватно-індивідуальний, платний, недержавний (побудований за системою платних освітніх послуг); інноваційно-проєктний (спрямований на впровадження новітнього досвіду з використанням інноваційних педагогічних технологій і такий, що фрінансується в межах цільових або інноваційних програм).

Поряд із фрормами систем вищої ступеневої освіти можна виділити деякі моделі навчання, які відрізняються одна від одної різними типами взаємодії в системі «викладач - курсант», способами мислення й діяльності під час освітнього процесу, а також мотиваційними чинниками особистостей майбутніх офріцерів ДКВС України щодо освіти протягом життя (рис. 1).

Розглянемо стисло кожну з моделей, що подані на рис. 1.

Так, модель «конвеєра» була спрямована на передачу глибоких класичних взірців знань із різних галузей науки, техніки, мистецтва тощо. Дана модель $€$ дуже ефрективною для передачі фрундаментальних знань, але ж украй віддалена від практики професійної діяльності. До того ж розвиток «конвеєрної» моделі відбувається завдяки множенню текстів й ускладненню програм, що не завжди покращує професійну мобільність майбутнього фрахівця будь-якої галузі діяльності, зокрема й пенітенціарної. На теперішній час дана модель освіти майже відходить, оскільки показала свою неефективність насамперед в організації системи вищої освіти, де велика частка навчального часу витрачається на монологічні форми навчання (лекції та семінари). Очевидним є той фракт, що 
дана система майже не застосовує тренінги, майстер-класи, тренажери, ділові ігри, проєктування та програмування, колективні форми взаємодії тощо. Адже саме такі фрорми покликані та спроможні «розконсервувати» конвеєрну підготовку майбутніх фрахівців, зробити їі більш прогресивною в усіх напрямах свого розвитку, а особливо розвитку особистості як викладача, так і осіб, які здобувають вищу освіту на будь-якому рівні. Суттєвим недоліком даної освітньої моделі $€$ й те, що в ній викладач виступає водночас носієм і транслятором знань, в також єдиним експертом рівня засвоєння навчального матеріалу особами, які навчаються.

Інфрорматизація освітньої сорери змінила можливості освітнього простору, зумовлиа появу проєктної та сітьової моделей. Дані моделі базуються на застосуванні різноманітних інорормаційних технологій та комп'ютерних програм (програмного забезпечення для розвитку, засвоєння та набуття певних профресійних навичок і вмінь). Ці моделі дозволяють крізь призму імітаційного програвання різних ситуацій, форм і кейсів практично орієнтованого характеру створити інтерактивне або електронне освітнє середовище, у якому застосовуються різні науково-практичні тексти, навчальні та навчально-методичні посібники, допоміжні матеріали (законодавчі акти, інструкції, регламенти, правила внутрішнього розпорядку установ виконання покарань, стандарти тощо), навчальні тренажери, лабораторії й імітаційні площадки для практичних занять, виконання завдань індивідуального або кафредрального наукового дослідження, що містяться на електронних носіях або виконуються за допомогою доступу до необхідної інформації та програмного забезпечення через Інтернет. Постійна робота над проєктами дозволяє курсанту - майбутньому офріцеру ДКВС України здобути той об'єм знань та набути певних навичок і вмінь, які йому допоможуть включитися у професійно-службову діяльність і згодом самостійно знаходити шляхи вдосконалення як особистої практики несення служби та виконання професійних завдань, так і загалом завдань певного структурного підрозділу ДКВС України.

Необхідність перебудови існуючої системи вищої освіти була зумовлена процесами євроінтеграції, імплементації міжнародного законодавства, інфрорматизації сфер діяльності суспільства, розвитком ринкових відносин та іншими чинниками, що, звісно, спричинило реформування всіх видів суспільних відносин, зокрема й в пенітенціарній системі. Виникла необхідність в офріцерах ДКВС України нової фрормації, які $€$ не вузькими професіоналами-виконавцями, а професіоналами, які спроможні до багатократної мобільності: які вміють швидко засвоювати нові профресійні ролі й фрункції, ухвалювати управлінські рішення, бути водночас

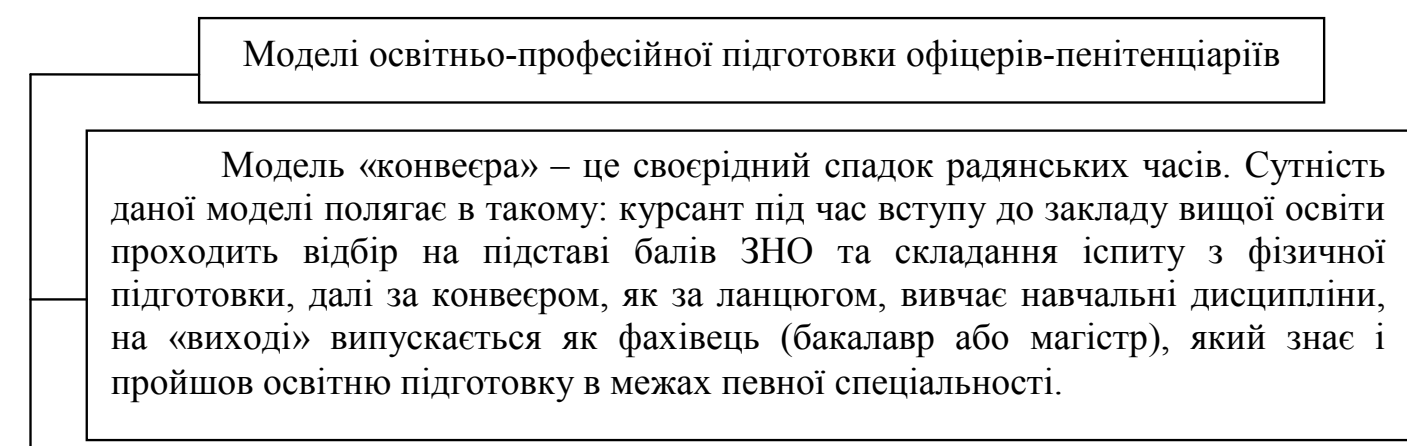

Проєктна модель відбиває деякі стандарти американської практикоорієнтованої системи світи, де курсанти одночасно із традиційними формами навчання закріплюються за кафедральними науково-практичними проєктами в межах своєї майбутньої професійної діяльності, до якої вони готуються протягом усього терміну навчання в закладі вищої освіти.

Сітьова модель організації освітнього процесу передбачає використання новітніх інформаційних технологій. У такій формі здобуття освіти самовизначення, самопроєктування й самоорганізація стають не випадковими, а педагогічно обгрунтованими методом неперервної освітньої діяльності. Дана модель є пошуковою, перебуває на стадії проєктних i пошукових (дослідницьких) робіт у багатьох сучасних закордонних закладах вищої освіти.

Рис. 1. Моделі освітньо-професійної підготовки майбутніх фахівців-пенітенціаріїв (авторська розробка) 
вихователями й педагогами для контингенту пенітенціарних закладів (установ виконання покарань, слідчих ізоляторів, арештних домів, уповноважених органів із питань пробації тощо), знаходити неординарні й водночас законні шляхи подолання складних ситуацій практичного службово-професійного характеру.

Саме тому консерватизм та інерційність, що й досі спостерігаються у вітчизняній системі вищої освіти і притаманні моделі «конвеєра», повинні поступово відійти, поступитися місцем інноваційним формам і методам навчання. Це складний процес, він пов'язаний також із необхідністю зміни мислення та світосприйняття, набуттям нових професійних компетентностей, насамперед викладачами закладів вищої освіти. Не є секретом, що й досі серед викладачів багатьох закладів вищої освіти працюють фрахівці 3 «ортодоксальними» поглядами на технології навчання. Саме вони створюють гальма на шляху впровадження нових освітніх технологій (форм і методів навчання), зміни взаємин у системах «викладач - викладач» і «викладач - курсант», застосуванні сучасних методів контролю знань курсантів, оскільки не бажають витрачати час на особисте професійне зростання. Безперечно, керівництво закладів вищої освіти повинно приділяти достатню увагу підвищенню кваліфрікації науково-педагогічних працівників, своєчасній зміні або звільненню їх із посад у разі невідповідності сучасним вимогам до їхніх профресійних компетентностей.

Сучасна система ступеневої вищої освіти, зокрема відомчої (спеціалізованої, наприклад, як підготовка майбутніх офріцерів-пенітенціаріїв для кримінально-виконавчої системи нашої країни), зможе стати базою для отримання професійного ресурсу, який буде сприяти розвитку ДкВС України й успішній рефрормі пенітенціарної сорери, за таких умов:

- основою фрормування повинна стати інноваційна складова частина як механізм саморозвитку самої системи ступеневої вищої освіти; саме інноваційність освітнього простору є тим ключовим чинником, що сприяє особистісному розвитку сучасного майбутнього фрахівця, фрормуванню його життєвих цінностей, мотиваційних траєкторій розвитку службово-професійної діяльності та нами цілого; 3) організаційна система: об'єднання людей, які спільно реалізують деяку програму або ціль і діють на підставі визначених процедур і правил.

Освітній простір, що побудований із застосуванням певних інноваційних складових частин, впливає на весь процес навчання, що виступає як складна система, яка поєднує риси наукової, практичної, культурно-художньої, ігрової та традиційної навчальної діяльності (які можуть бути предметом додаткового вивчення). До речі, потрібно звернути увагу на той фракт, що наукова діяльність орга- нічно пов'язана з безперервним процесом підвищення рівня знань: як тільки науково-педагогічний працівник (викладач) припиняє вчитися, він уже не $€$ дослідником і вченим, він втрачає здатність до самоосвіти та ризикує не тільки відстати від часу, але й узагалі втратити викладацьку роботу. Це ще й означає, що такий науково-педагогічний працівник вже не може дати інноваційні знання прогресивній молоді - курсантам, не може залучити їх до процесу срормування стійкої мотивації та прагнення отримати більш нової інформації, виконати якісно наукові індивідуальні дослідження, до яких курсанти можуть і повинні бути залучені, тобто «привити» їм стійке бажання навчатися протягом життя й отримувати від цього задоволення тощо.

Неможливо залишити поза увагою й те, що сучасна освіта, навчальний процес, освітній простір закладу вищої освіти повинні відповідати певному рівню культури. Ці складові частини простору для формування професійної компетентності майбутніх ооріцерів ДКВС України містять всі типи організаційної культури й історично еволюціонують до інноваційних технологій.

Перша й найбільш давня форма навчання буденно-практичне навчання. Воно зберігається й досі, водночас праця не потребує спеціальної освіти та засвоюється методами спостереження й наслідування.

Друга історична форма навчання - це демонстративне навчання, що до цього часу входить у навчальний процес, хоча багатьма вченими-педагогами вважається застарілим. Звичайна демонстрація як метод навчання залишається однією із традиційних фрорм організації навчального процесу, де науково-педагогічний працівник (викладач) суб'єкт, а курсант - об'єкт навчальної діяльності.

Третя фрорма організації навчального процесу - розвиваюче навчання, коли науково-педагогічний працівник (викладач) пояснює всебічно об'єкт і предмет дослідження, явища та процеси, що супроводжують певні ситуації або проблемні завдання, а курсант вникає в навчальні матеріали і багато відпрацьовує самостійно. За такої форми відпрацьовуються певні навички самостійно вирішувати завдання, нести відповідальність за результати навчання, тобто особистісну якість та успішність навчання. Водночас науково-педагогічний працівник (викладач) повинен ставитися до курсанта як до особистості 3 індивідуальними психологічними та розумовими властивостями, ураховувати їх для досягнення максимального ефекту передачі знань, фрормування вмінь і навичок, професійних компетентностей, організаційної культури спілкування, мотивації до постійного розвитку тощо. У демонстративному й розвиваючому навчанні науково-педагогічний працівник (викладач) залишається «поводирем» у лабіринті знань, умінь та навичок, він працює не з окремою особис- 
тістю, а 3 «аудиторною групою», водночас організовує навчальний процес кожного за єдиним стандартним планом. Потрібно розуміти, що навіть в одній «аудиторній групі» викладач змушений застосовувати до курсантів різні методи навчання, що залежать від їхнього ставлення до навчання й особистісних здатностей. Тому в різних «аудиторних групах» може сорормуватися неоднакове ставлення до навчання.

Сучасний етап розвитку вищої освіти й освіти загалом характеризується новою концепцією, що містить нові інфрормаційні та психолого-педагогічні складові частини, відбиваючи креативність, інформативно-інноваційні та комплексні (компетентнісний, інтегративний, системний та інші) підходи до фрормування професійних знань, умінь і навичок, сучасних компетентностей, мотивацію до освіти протягом життя. Сьогодні головним завданням навчального процесу, що відбувається в сучасному інноваційно-інформаційному освітньому середовищі, є розвиток у курсантів здібностей до самостійного формування нових для них професійних компетентностей, способів дій в умовах невизначеності, певних складних ситуацій, що можуть виникнути й виникають під час практичної службово-професійної діяльності. Головним чинником креативного навчання $€$ ініціативність курсанта як повноправного суб'єкта спілкування 3 науково-педагогічним працівником (викладачем), що відбувається в інноваційно-інформаційному освітньому середовищі.

Методи креативного навчання поступово увійшли в навчальний процес багатьох вишів, розвиваються й удосконалюються залежно від профрілю навчання. Головне, що такі методи завжди спрямовані на живий людський контакт партнерів навчального процесу (викладачі й курсанти), які зацікавлені один в одному і на практиці в системі «науково-педагогічний працівник (викладач) - курсант» виконують спільну працю, спрямовану на досягнення якісного результату та певного мотиваційного рівня щодо навчання протягом життя. Науково-педагогічний працівник (викладач) уже не $€$ «поводирем», він $є$ людиною - особистістю, яка володіє великим об'ємом сучасних знань і вмінь, має авторитет серед курсантів, яким і притягує їх до спільної науково-практичної та навчальної, творчої діяльності, а також це дає викладачу можливість давати доречні поради особам, які навчаються. Відносини між науково-педагогічним працівником (викладачем) і курсантами набувають характеру неформального, особистісного (не тільки фрункціонально-рольового) спілкування в межах організаційної корпоративної культури. У таке спілкування втягуються не тільки інтелект, але й емоції, воля, моральні й соціальні почуття курсанта. Водночас науково-педагогічний працівник (викладач) не просто виконує обов'язки, що спрямовані на розвиток курсанта, а й проникає в його духовний світ як людина, що стає йому близькою в період навчання в закладі вищої освіти.

Креативні й нестандартні заняття у процесі навчання - це вже, власне, не «навчальний процес» як система педагогічних заходів, а інноваційна практико-орієнтована діяльність, чітко спрямована на розвиток особистісних характеристик курсанта відповідно з його психологічними особливостями. Така система навчання не буде працювати, якщо курсант безвідповідальний, безініціативний, не бажає або не здатний діяти самостійно, а науково-педагогічний працівник (викладач) байдужий до інтересів курсанта.

Спільна праця науково-педагогічного працівника (викладача) та курсанта у процесі креативного навчання - це їхня творчість, що відображається згодом на рівні не тільки результатів навчання - сорормованих професійних компетентностей, а й на рівні культури спілкування, рівні мотивації, інноваційного мислення, стійкого прагнення до профресійного зростання протягом усього подальшого життя.

у моделі креативного навчання частково наявне повернення до моделі буденно-практичного навчання, оскільки вона зливається із життям. Однак і ця часткова фрорма набуває нового змісту: курсант спостерігає й повторює методи й форми наукової, навчальної, іншої роботи науково-педагогічного працівника (викладача), але він виявляє себе як творчо обізнана людина, як особистість, яка має інноваційні погляди на певні проблеми та їх рішення, як самостійно діючий суб'єкт процесу навчання, який вільно виражає свої думки та творчі здібності.

Безумовно, для задоволення соціально-економічних, культурних, моральних, духовних потреб сучасного суспільства, різних сорер діяльності людини, зокрема й пенітенціарної, необхідно розширювати сореру креативного навчання, що спроможне досить якісно сорормувати практико-орієнтоване мислення осіб, які навчаються (курсантів), трансорормувати освітнє середовище в таке, що спроможне «виростити» інноваційну особистість, яка, поринувши у світ службово-професійної діяльності, буде спроможна самостійно та якісно виконувати завдання служби та бути гідною людиною.

Висновки. Викладені результати дослідження дають змогу зробити такі висновки:

- процес удосконалення методології підготовки майбутніх офріцерів-пенітенціаріїв $€$ живим, постійно рухається залежно від певних вимог щодо професійних компетентностей фрахівців, службово-професійна діяльність є важливою для повернення до суспільства осіб, які скоїли злочини та пройшли певний шлях ресоціалізації в пенітенціарних закладах, а також для гарантування безпеки суспільства і країни загалом; 
- зважаючи на існування різних форм і методів навчання, необхідно віддавати перевагу тим, що сприяють інноваційності розвитку майбутнього офріцера-пенітенціарія, надають йому змогу сфрормувати протягом навчання в закладі вищої освіти зі специфрічними умовами навчання певні професійні компетентності, набути навичок і вмінь у реалізації власного розумового потенціалу, застосування його для професійного зростання та навчання протягом життя;

- ураховуючи те, що сучасний світ стрімко розвивається, уважаємо за необхідне розвивати креативне мислення та творчий підхід до створення інфрормаційно-інноваційного освітнього середовища, умов, фрорм і методів навчання, що сприяють виникненню й зміцненню стійкості мотивації в майбутніх офріцерів-пенітенціаріїв до особистісного неперервного розвитку.

Усе це надасть можливості «виростити» гідних майбутніх офріцерів ДКВС України, здатних творчо й професійно підходити до вирішення завдань різного рівня складності під час здійснення службовопрофесійної діяльності, а подальші дослідження будуть спрямовані на пошук нових креативних форм інноваційного розвитку і творчого мислення майбутніх офріцерів-пенітенціаріїв.

\section{БІБЛІОГРАФІЧНИЙ СПИСОК:}

1. Болотов В. Компетентностная модель: от идеи к образовательной программе. Педагогика. 2003. № 10. С. 8-14.

2. Голубцова І. Особливості застосування інтерактивних технологій. Організація навчально-виховного процесу. 2007. № 9. С. 159-174.

3. Johnson K., Magusin E. Exploring the digital library. A guide for online teaching and learning. JosseyBass, 2005. 162 p.
4. Драйден Г., Вос Дж. Революция в обучении. Научить мир учиться по-новому. Москва : Парвинэ, 2003. $670 \mathrm{c}$.

5. Зимняя И. Ключевые компетентности как результативно-целевая основа компетентностного подхода в образовании. Москва : Исследовательский центр проблем качества подготовки специалистов, 2004. 42 c.

6. Кларин М. Инновации в мировой педагогике: обучение на основе исследования, игры и дискуссии (Анализ зарубежного опыта). Рига : НПЦ «Эксперимент», 1995. 176 с.

7. Койл Э. Подход к управлению тюрьмой с позиций человека. Лондон : МЦТИ, 2002. 160 c. URL: http://www.prisonstudies.org/russian.pdf.

8. Либлинг А., Прайс Д., Шефер Г. Тюремный работник. Рутледж, 2012. С. 163.

9. Освітні технології : навчально-методичний посібник / О. Пєхота та ін. Київ : А.С.К., 2001. 256 с.

10. Пометун О., Пироженко Л. Інтерактивні технології навчання : теорія, практика, досвід. Київ, 2002. 135 c.

11. Resta Paul (ed.). Information and Communication Technologies in Teacher Education. A Planning Guide. UNESCO : Division of Higher Education, 2002. 237 p.

12. Синьов В. Підготовка спеціалістів для пенітенціарної системи. Проблеми пенітенціарної теорії $i$ практики. 1996. № 1. С. 17-24.

13. Тогочинський О. Теорія і практика фрормування соціальної компетентності слухачів та курсантів вищих навчальних закладів МВС України: монографрія. Чернігів : Десна Поліграфр, 2015. 488 с.

14. Торічний О. Потенціал інтерактивних технологій у формуванні фрахової компетентності майбутніх офріцерів-прикордонників. Збірник наукових праць Національної академії Державної прикордонної служби України. Серія «Педагогічні науки». 2016. № 1. С. 186-198.

15. Сучасні педагогічні технології : навчальнометодичний посібник / автор-укладач Е. Федорчук. Кам'янець-Подільський : Абетка, 2006. 212 с. 